\title{
Enhancement of Aeribacillus pallidus lipase production through optimization of medium composition using Box behnken design and its application in detergents formulations
}

\author{
Ameni KTATA \\ Ecole Nationale d'Ingenieurs de Sfax \\ karray aida ( $\sim$ karrayaida_biotech@yahoo.fr) \\ Ecole Nationale d'Ingenieurs de Sfax \\ Ines Mnif \\ Ecole Nationale d'Ingenieurs de Sfax \\ Sofiane BEZZINE \\ Ecole Nationale d'Ingenieurs de Sfax
}

\section{Research article}

Keywords: Aeribacillus pallidus, Response surface methodology, lipase, themostable, detergent formulation.

Posted Date: October 8th, 2019

DOI: https://doi.org/10.21203/rs.2.11777/v2

License: (c) (1) This work is licensed under a Creative Commons Attribution 4.0 International License.

Read Full License 


\section{Abstract}

Background : Alkaline, thermostable bacterial lipases are very interested at detergent applications, seen that they replace the use of synthetic detergents which cause substantial environmental problems. These enzymes based detergent are eco friendly and produce a waste water with low level of COD (Chemical Oxygen Demand). The present study, investigates a newly isolated Aeribacillus pallidus strain produces, without induction, a novel halophilous, thermo-alkaline and detergent- tolerant lipase. Results: Considerable interest has been given to this lipase by the improvement of its production by the optimization of the $\mathrm{pH}$, the $(\mathrm{C} / \mathrm{N})$ ratio and the inoculums size, using the response surface methodology based on the Box-Behnken Design of experiments. A total of 16 experiments were conducted, and the optimized $\mathrm{pH},(\mathrm{C} / \mathrm{N})$ ratio and inoculums size were 10,1 and 0.3 respectively. The results of the analysis of variance (ANOVA) test indicated that the established model was significant ( $p$ value $<0.05$ ). Conclusions: A 6.68-fold of increase in enzyme activity was revealed under the optimized conditions with the maximum activity of $68 \mathrm{U} / \mathrm{mL}$. Additionally, lipase of Aeribacillus pallidus is considered as a potential candidate for applications in detergent formulations since it displayed a good stability towards detergents and wash performance.

\section{Background}

Lipases are hydrolytic enzymes which are acquiring more importance for industrial applications. Hence, lipases can be incorporated in food industry, in fact, they are used as emulsifiers in the improvement of baked products and pasta (Houde et al., 2004), and also they are used to modify flavours and produce fragrance compounds (Ferreira-Dias et al., 2015). Evenly, they are used in detergence as additives, providing that they are active and stable at high temperatures and alkaline $\mathrm{pH}$, by the removal of oils and fats from cotton fabrics (Pandey et al., 1999; Veerapagu et al., 2013). These hydrolytic enzymes are equally used in wastewater treatment by the biodegradation of oils (Boran et al., 2019), in leather industry by the elimination of fat from animal skin (Das et al., 2016).Further applications of lipases have been described such as medical applications (as new drugs for treatment of digestive aids and high cholesterol levels) (Hasan et al., 2006), textile industry (Hasan et al., 2006)...

These enzymes are found in various microorganisms including yeast, fungi and bacteria (Nagarajan, 2012).

While, despite the high biotechnological potential of lipases in various fields, the yields of their production is one of the most crucial factors to be developed. Thus, the optimization of culture media is substantial, because of lipase production is influenced mainly by the type and concentration of the carbon source, nitrogen source and inducers (Muralidhar et al., 2001) by varying one factor at a time which does guarantee to reach the optimal point (Strobel et Sullivan 1999). As such, recent studies of optimizing the medium components for lipase production have proved that using Plackett-Burman Design (PBD) and Response Surface Methodology (RSM) approaches, whose Box-Benkhen design is one among them (Box and Behnken 1960), were able to be the most effective methods (Gupta et al. 2007; He and Tan, 2006), 
which are able to overcome the drawabcks of the one factor at time the fact that, they creates empirical model equations that correlate the relationship between variables and responses. Consequently, RSM has so many advantages, and has successfully been applied to study and optimize the enzymatic processes (Soo et al.2004; Basri et al.2007) and enzyme production from microorganisms (Gaur et al.2008; Teng et $\mathrm{Xu}, 2008$ )

In the present investigation, we aimed to improve the yield of lipase production through optimization of the fermentation medium composition for a newly thermostable lipase of Aeribacillus pallidus. Additionally, the enzyme showed excellent stability and compatibility with various commercial detergents suggesting its potential as an additive in detergent formulations.

\section{Results}

\subsection{Preliminary optimization using "one-factor -at-a-time"}

Aeribacillus pallidus produced about $24 \mathrm{U} / \mathrm{mL}$ of lipase in the production medium, at $\mathrm{pH} 10$ and $65^{\circ} \mathrm{C}$ in the presence of $1 \mathrm{mM}$ sodium taurodeoxycholate (NaTDC) and $1 \mathrm{mM} \mathrm{CaCl} 2$ after $22 \mathrm{~h}$ of incubation. After this period, lipase activity began to decrease.

The improvement of microbial lipase production is the purpose of several investigations. According to maximizing enzyme production, each strain has its specific requirement in culture conditions. Various components in the media such as carbon and nitrogen substrates which affect the carbon to nitrogen ratio $(\mathrm{C} / \mathrm{N})$ which consequently influence the production of extracellular lipase enzyme (Jia et al. 2015) as shown in table 1 . We discussed about the effect of $\mathrm{C} / \mathrm{N}$ ratio thereinafter.

\subsection{Effect of carbon source on lipase activity}

The major factor affecting expression of lipase is the carbon source. Most of reports available, state that lipases are generally induced by natural oils (He and Tan 2006; Kaushik et al.2006; Abdel-Fattah 2002), and high levels of lipase production were reported from various thermophilic Bacillus sp (Eltaweel et al.2005; Bora and Kalita 2007; Lee et al.1999). While the main observation of Box-Behnkhen study was the poor induction of lipase of Aeribacillus pallidus by oils. In fact, various carbon sources were tested, glycerol, Tween 80 , Olive oil, Glucose, Fructose and Sucrose at final concentration $1 \%$ were analyzed independently ( Fig. 1). Culture supernatants were sampled at different times during $24 \mathrm{~h}$ of growth and assayed for their lipase activity. Statistical analyses of the results showed that the highest lipase activity determined in the culture broth was obtained after $22 \mathrm{~h}$ of incubation. Therefore, only the results determined after this time of incubation were taken into account (fig 2). Statistical analysis of the results showed that lipase was significantly improved when glucose was used as the sole carbon source with 1.5 $\%$ (Fig. 2), to reach a better GPL activity with $32 \mathrm{U} / \mathrm{mL}$. This result is in contradiction with those having shown that carbon sources are easily broken down and used by bacteria to play an inhibitory role ( Lee et al.1999; Gowland et al 1987, Mates and Sudakevitz 1973). 
For further comparisons, the glucose effect on Staphylococcus xylosus lipase showed the same behaviour, with an optimal activity measured using $2.5 \%$ glucose (Ghribi et al.2009).

\subsection{Effect of organic and inorganic nitrogen source on lipase activity}

In addition to carbon source, the source of nitrogen is an important parameter for lipase production, and to obtain an insight for the effect of different nitrogen sources, various organic and inorganic sources were investigated in lipase production. Generally, when organic nitrogen sources were used such as peptone and yeast extract, high level of lipase production by various thermophilic Bacillus sp (Ghanem et al.2000; Sharma et al.2002; Sugihara et al.1991) was observed. So that, yeast extract is one of the most important organic nitrogen sources for high level lipase production by different microorganisms (Bora and Kalita 2007), and this is in accordance with our results. As shown in (Fig.3a), higher lipase activity was obtained when yeast extract was used as organic nitrogen source rather than using Soya Peptone, Tryptone, Pancreatic Digest Peptone and Casein Peptone. Since, $0.05 \%$ yeast extract is enough to improve significantly lipase activity reaching $34 \mathrm{U} / \mathrm{mL}$. However, the lipase activity decrease significantly when using Soya Peptone, Tryptone, Pancreatic Digest Peptone and Casein Peptone.

The requirement of the source of nitrogen depend on microorganisms, some of them show preference to organic forms, while others show preference to the inorganic forms. Both organic and inorganic forms are required for some microorganisms. When, we tested the inorganic sources (Ammonium chloride $\left(\mathrm{NH}_{4} \mathrm{Cl}\right)$, ammonium nitrate $\left(\mathrm{NH}_{4} \mathrm{NO}_{3}\right)$, ammonium sulphate $\left(\left(\mathrm{NH}_{4}\right)_{2} \mathrm{SO}_{4}\right)$, ammonium molybdate $\left(\left(\mathrm{NH}_{4}\right)_{6} \mathrm{Mo}_{7} \mathrm{O}_{24}\right.$ and $\mathrm{HgN}_{2} \mathrm{O}_{4} \mathrm{~T}$ ), it was found that the combination of inorganic and organic nitrogen in the form of $\mathrm{NH}_{4} \mathrm{Cl}$ among all the other forms tested with $0.05 \%$ yeast extract improve the lipase production to $36 \mathrm{U} / \mathrm{mL}$ (Fig. 3.b).While the omitting of one of them lead to a sharp decrease of the lipase activity.

Several investigation have shown that a combination of organic and inorganic nitrogen sources has been used for lipase production from Bacillus strain A30-1(Wang et al.1995), Pseudomonas sp., (Dong et al.1999)and $P$. aeruginosa LP602 (Dharmsthiti and Kuhasuntisuk 1998) and it was also found that with higher concentration of ammonium chloride (2.5\%), lipase production was drastically increased by almost fourfold.

A 6.68-fold increase for lipase production was obtained by one variable at a time. The variation of the concentration of inorganic nitrogen source (Ammonium chloride) in our study affects the $\mathrm{C} / \mathrm{N}$ ratio. The results shown in table 2, statistically analyzed according to Duncan's test realized after ANOVA analysis, were obtained by using $1.5 \%$ glucose, $0.05 \%$ yeast extract and various $\mathrm{C} / \mathrm{N}$ ratios corresponding to various ammonium chloride concentration. With the values of $(\mathrm{C} / \mathrm{N}=1)$, which is corresponding to $1.5 \%$ glucose and 2.3\% $\mathrm{NH}_{4} \mathrm{Cl}$, the optimal lipase activity was detected and reaches $36 \mathrm{U} / \mathrm{mL}$. Up over this $\mathrm{C} / \mathrm{N}$ ration, a decrease of lipase activity was significantly observed, reaching $18 \mathrm{U} / \mathrm{mL}$ for $\mathrm{C} / \mathrm{N}$ of 6 .

In conclusion, using $0.5 \mathrm{~g} / \mathrm{l}$ yeast extract and applying a $\mathrm{C} / \mathrm{N}$ ration equal to 1 , the optimal activity of GPL reaches $36 \mathrm{U} / \mathrm{mL}$. 
These results show that to provide amino acids and vitamins necessary for metabolite production, a balance between organic and inorganic nitrogen sources and suitable values of $\mathrm{C} / \mathrm{N}$ ratio must be taken into account.

\subsection{Optimization of medium components using response surface methodology}

In order to optimize medium culture and to improve lipase production by Aeribacillus pallidus, a statistical analysis based on experimental design was adopted. This experimental planification methodology is a valuable tool for optimizing the medium of lipase production which provide advantages: the use of multifactor effects, the obtaining of the optimum values and the developing of a system model with substantially less experimental requirements (Wu et al.2007).

Several studies have been shown to increase lipase production for several folds by a large wide of organisms (He and Tan 2006) such as Aspergillus niger (Soo et al.2004), Staphylococcus xylosus (Sharon et al 1998), Candida cylindracea (Jia et al.2015) and Geobacillus sp (Abdel-Fattah, 2002).

\subsection{Data Analysis and Modeling}

Based on the OFAT experiments, which indicated that Glucose, ammonium chloride, inoculums size and $\mathrm{pH}$ are the significant factors, affecting the GPL activity, Box-Behnken Design was used to determine the optimum conditions for these significant factors (carbon to nitrogen $(\mathrm{C} / \mathrm{N})$ ratio $(\mathrm{X} 1), \mathrm{pH}(\mathrm{X} 2)$, inoculums size (X3)). The experimental design, experimental and predicted values for lipase production obtained from the regression equation for 16 combinations were shown in (Table 1). The results demonstrated that there is a considerable variation in lipase activity produced by Aeribacillus pallidus. Indeed, the highest level of lipase activity was $68 \mathrm{U} / \mathrm{mL}$ (run3) and the lowest amount was 30; $34 \mathrm{U} / \mathrm{mL}$ (run 6, 8 and 9).

Statistical analysis of variance (Table 3) was used to investigate the effectiveness of the model. The Fvalue (Fisher's statistical analysis) was used as tool for evaluating the significance of the model. It was estimated to be 87.18 , that's mean that there is only a $12.82 \%$ chance of "F-value Model" taking place due to noise.

The coefficient of determination $\left(R^{2}\right)$ is a measure of the quality of the prediction of a linear regression. Generally, its determination and its prediction of the response is significant when it is close to 1 (Haaland, 1989; Kaushik et al.2006). In this model, it is calculated to be 0.992 . This is shows a good correlation between experimental and predicted values. Hence, only $21.53 \%$ of the total variations are not interpreted by the model. This indicates a satisfactory representation of the process by the model. In addition, a high degree of similarity was obtained between the predicted and experimental values suggesting the significance of the regression model describing the response which was proved the suitability of the model even (fig. 4).

\subsection{D Response Surface and contour Plots Analysis}


Response surface and contour plots have been used in order to understand and define the effect of the studied variables within the experimental space. This technique was achieved by depicting the interactions between two variables while keeping the third at a constant level (Ghribi et al.2011). Thus, 3D responses facilated the visual determination of optimum levels of each parameter. Therefore, in the first time (Fig. 5.a) we fixed the inoculum size at its zero-coded level OD600 $=0.3$. So, the response was represented as function of the interaction between liquid substrate ratio and $\mathrm{pH}$ level. It can be clear that lower than their central level, the carbon to nitrogen $(\mathrm{C} / \mathrm{N})$ ratio and $\mathrm{pH}$ significantly influenced the enzyme production.

As shown in Fig.5.b and Fig. 5.c, the iso-responses are near parallel to the inoculum size axis. This suggests that neither an increase nor a decrease in inoculum size can affect significantly the lipase activity.

As analyzed in the present study, a successful and significant improvement from $30 \mathrm{U} / \mathrm{mL}$ to $68 \mathrm{U} / \mathrm{mL}$ in the production of lipase was accomplished, when the respective values of carbon to nitrogen $(\mathrm{C} / \mathrm{N})$ ratio (X1), pH (X2), and inoculums size (X3) are 1, 10 and 0.3 respectively. Indeed, a 3-fold increase in lipase yield after optimisation was observed, with $300 \%$ increase in T1 lipase production by Pichia guilliermondii (Ladidi et al.2017).

\subsection{Stability and compatibility on GPL with laundry detergents}

A detergent is a mixture of surfactants and oxidizing agents that show their cleaning efficiency at alkaline $\mathrm{pH}(9-11)$. Fig. 6 proves that lipase of Aeribacillus pallidus was highly stable and compatible with commercial solid detergents used; in fact, it retained $98 \%, 96 \%, 95 \%$ and $90 \%$ of its initial activity with Dixan,OMO, Nadhif and Ariel, respectively, after incubation of $30 \mathrm{~min}$. In addition, in the present of liquid laundry detergents, GPL was highly stable; it retained $100 \%$ of its original activity in Dipex when incubated $1 \mathrm{~h}$ at $50^{\circ} \mathrm{C}$, while only $80 \%$ were retained when incubated in Ariel.

Enzyme activity of the control sample, which contained no additive and incubated under similar conditions, was taken as $100 \%$. Each point represents the mean of three independent experiments.

These results are consistent with those reported for alkaline lipases from Bacillus stearothermophilus (Ben bacha et al.2015), Bacillus stratosphericus (Zin et al.2017). Results show clearly that lipase of Aeribacillus pallidus can provide further support for its usefulness for future industrial application as a cleaning bioadditive in detergent compositions.

\subsection{Removal of oil spot from cotton fabrics}

To evaluate the performance of lipase of Aeribacillus pallidus in terms of its ability to remove oil spot, several pieces of stained white cotton were incubated at different conditions. As shown in Fig. 7, the limited washing performance was observed with detergent (Dixan) only, and its supplementation seems to improve the cleaning process as evidenced by oil spot removal when compared to detergent alone. 
Furthermore, the combination of this enzyme with the Dixan detergent resulted a complete oil spot removal.

\section{Discussion}

In the present investigation, we aimed to produce a high level of lipase production of Aeribacillus pallidus, using the optimization of response surface methodology, due to its relevance. Results presented in this paper, showed that an overproduction of GPL was reached under aerobic conditions by glucose at high concentrations, a combination between organic and inorganic nitrogen sources, $\mathrm{pH} 10$ and inoculums size equal to 0.3 .

As long as, the major factor affecting the lipase activity has always been carbon source, as lipases are generally inducible enzymes (Lotti et al. 1998). In fact, the use of glucose as carbon source to the culture medium improve well the aerobic growth, the biomass formation and the productivity of the lipase (Fig.2), while its decrease in the presence of lipid source such as tween, glycerol and olive oil, this can be explained by he fact that glucose is the most readily metabolized carbohydrates and a source of fast energy (Madigan et al. 2003).

After $22 \mathrm{~h}$ of incubation, lipase activity began to decrease, might be due to the exhaustion of nutrients, accumulation of toxic, and the change in $\mathrm{pH}$ of the medium, or proteolysis of lipase by proteases which were produced simultaneously (Nouroozi et al. 2015). An excessive increase of the glucose concentration decrease both the lipase activity and cells formation (Fig. 2), it could be explained by the fact that the cells produced at high glucose concentrations are not physiologically able to synthesize lipases, this phenomenon can be observed in facultative anaerobic bacteria such as Bacillus thuringiensis (Al-mhanna, 2010)..

Yeast extract increase the productivity for the most of microorganisms (Bora and Kalita 2007), thanks to its wealth of vitamins and trace elements for the growth of bacteria and increases their lipase production (Gupta et al. 2007). Whereas, the decrease of lipase activity when using peptone as organic nitrogen source, could due to its complex composition which can cause toxic effects by one of its components (Sooch and Kauldhar 2013).

An other substantial factor for the productivity of lipase is the $\mathrm{pH}$. The $\mathrm{pH}$ not only acts on enzymatic activity but also on the properties of the interface in a multiphasic system, on the solubility of the reagents in the medium, as well as the sharing of the enzyme between the aqueous phase and the interface. The optimum $\mathrm{pH}$ of lipase activity is usually around 7 while bacterial lipases generally have a slightly basic optimum pH (8- 8.5) (Sharma et al. 2001); (Gargouri et al. 2008).

Most halophilic lipases showed maximal production at $\mathrm{pH}$ alkalin and temperature up to $40^{\circ} \mathrm{C}$ (Esakkiraj et al. 2014); (Li et al. 2014). Seen that Aeribacillus pallidus grew at $30 \mathrm{~g} / \mathrm{l} \mathrm{NaCl}$ in the culture medium, at $55^{\circ} \mathrm{C}$ and lipase was active under these conditions (Ktata et al. 2018) , GPL was considered as a thermoactive and haloalkaliphilic lipases (Gupta et al. 2007 ; Marques et al. 2014; Yoo et al. 2011). 
Lipases used in detergents must have a broad spectrum of substrates and be able to withstand washing conditions such as $\mathrm{pH}$ values between 10 and 11 , and a temperature of between $30^{\circ} \mathrm{C}$ and $60^{\circ} \mathrm{C}$, thus, this novel lipase are especially sought-after. Once the lipids are partially or fully hydrolyzed by the enzyme, becomes easier to extract from the washed fabric. In fact, an alkaline lipase was reported, produced by Pseudomonas alcaligenes $\mathrm{M}-1$, which was well adapted to remove fatty stains under wash conditions (Gerritse et al. 1998).

Thus, the performance of a good detergent lipase is defined by multiple parameters such as: the thermostability feature of lipase of Aeribacillus pallidus (Bora and Bora 2012), the ability to hydrolyze several types of triglycerides (short, medium and long chain) and its compatibility with other detergent components, support the usefulness of lipase of Aeribacillus pallidus in future industrial applications as a cleaning bioadditive in detergent formulations. In summary, GPL could have a good capacity for removing fatty stains in alkalin environment, suggesting its potential use as an additive in detergent formulations.

\section{Conclusion}

Experimental planning methodology was used in our study as a tool to significantly increase the production yields of Aeribacillus pallidus lipase GPL and predict the optimal values of the important influent factors. A Box-Behnken design with three optimal factors was applied ( $\mathrm{C} / \mathrm{N}$ ratio, $\mathrm{pH}$ value and inoculums size). A high degree of similarity was obtained between the predicted and experimental values suggesting the significance of the regression model describing the response. This novel lipase showed excellent stability and compatibility with various commercial detergents, suggesting its potential use as an additive in detergent formulations.

\section{Materials And Methods}

\subsection{Source of strains}

Strains were previously isolated from the production water (an oil/water mixture) of the oil-field managed by Thyna Petroleum Services (TPS), located at $11 \mathrm{~km}$ northwest of Sfax city, Tunisia (Mnif et al.2014). The formation water deposit from depths of $1300 \mathrm{~m}$ at a temperature of $78{ }^{\circ} \mathrm{C}$, a salinity of $100 \mathrm{~g} / \mathrm{L}$ and a $\mathrm{pH}$ of 7.6. Samples were directly collected in sterile bottles and stored in dark at $4{ }^{\circ} \mathrm{C}$ until use.

\subsection{Lipase production at shake flask scale}

The thermoalkaline lipase from Aeribacillus pallidus (GPL) was produced using the optimized medium which is composed of ( $\mathrm{g} / 1): 30 \mathrm{~g} \mathrm{NaCl}, 1 \mathrm{~g} \mathrm{KH} 2 \mathrm{PO} 4,0.4 \mathrm{~g} \mathrm{NH} 4 \mathrm{Cl}, 1 \mathrm{~g} \mathrm{MgSO} 4.6 \mathrm{H} 2 \mathrm{O}, 1 \mathrm{~g} \mathrm{CaCl} 2,0.5 \mathrm{~g}$ yeast extract and $1 \mathrm{~mL}$ trace-element solution (Jaouadi et al.2009) in $1 \mathrm{~L}$ of distilled water. The pH was adjusted with $4 \mathrm{M} \mathrm{KOH}$ solution to 7.4. Aliquots of $50 \mathrm{~mL}$ were dispensed into flasks and sterilized by autoclaving at $121^{\circ} \mathrm{C}$ for $20 \mathrm{~min}$. These flasks were incubated at $55^{\circ} \mathrm{C}$ under aerobic conditions for $22 \mathrm{~h}$ 
with shaking at $200 \mathrm{rpm}$. Before each assay, the microbial cell debris was removed by centrifugation at $13000 \mathrm{rpm}$ for $30 \mathrm{~min}$. Next, the obtained clear supernatant was used as a crude enzyme preparation.

\subsection{Lipase activity and protein estimation}

The lipase activity was measured titrimetrically at $\mathrm{pH} 10$ and $65^{\circ} \mathrm{C}$ with a pH-stat under standard

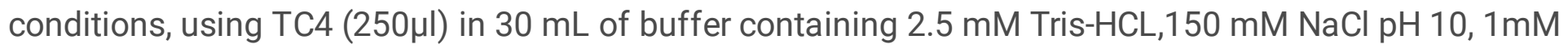
$\mathrm{CaCl}_{2}$ and $1 \mathrm{mM}$ sodium taurodeoxycholate (NaTDC) or olive oil emulsion whose obtained by mixing 10 $\mathrm{mL}$ of olive oil in $90 \mathrm{~mL}$ of $10 \%(\mathrm{w} / \mathrm{w}$ ) gum Arabic (for 3x 30s) in a Waring blender. One unit of lipase activity corresponds to $1 \mu \mathrm{mol}$ of fatty acid released per minute under the assay conditions used.

Protein content was measured by Bradford method (Bradford, 1976), using bovine serum albumin as standard.

\subsection{Medium optimization for maximum lipase production by Aeribacillus pallidus using Statistical Procedure}

Lipase production optimization was carried out using experimental planification methodology through the response surface methodology. Preliminary studies through one factor at a time have proved that ratio $\mathrm{C} / \mathrm{N}, \mathrm{pH}$ and inoculum size affect significantly lipase production. Therefore, in order to determine the optimum levels of these three significant variables, to predict the possible interaction between them and to enhance lipase activity, a Box-Benkhen design for three independent variables was adopted. It was generated using NemrodW version 2007 software (LPRAl,Marseille, France).

\subsection{One-factor-at-a-time (OFAT)}

Firstly, the classical one-factor-at-a-time (OFAT) approach was employed to evaluate the influential parameters on the lipase production. In the first step of culture conditions optimization, we have started with optimizing the carbon source, the organic and inorganic nitrogen source, and their concentrations, the inoculums size and $\mathrm{pH}$.

These parameters were optimized by keeping all factors at a constant level in the basal medium, except the one under study and each subsequent factor was examined after taking into account the previously optimized factor(s).

\subsection{Optimization of nutritional parameters}

In one's element, the name of Aeribacillus pallidus has been reassigned to Geobacillus pallidus (Minana Galbis et al.2010), owing to DNA composition level, fatty acid composition and the polar lipid profile (Chamkha et al.2008). This strain is a Gram-positive bacterium, aerobic, thermophilic, halotolerant (Minana Galbis et al.2010). 
To select the best carbon source that maximizes lipase production for this strain, various carbon sources were tested, as, glycerol, Tween 80 , Olive oil, Glucose, Fructose and Sucrose at final concentration $1 \%$. The concentration of the selected carbon source was then varied in the range of $0-2 \%$ to work out the optimum concentrations.

The effects of nitrogen sources were evenly evaluated, with various organic and inorganic nitrogen sources at the same final nitrogen concentration. For organic sources, we have already used (yeast extract, peptone, soya peptone, casein peptone and tryptone) when the Ammonium chloride $\left(\mathrm{NH}_{4} \mathrm{Cl}\right)$, ammonium nitrate $\left(\mathrm{NH}_{4} \mathrm{NO}_{3}\right)$, ammonium sulphate $\left(\left(\mathrm{NH}_{4}\right)_{2} \mathrm{SO}_{4}\right)$, ammonium molybdate $\left(\left(\mathrm{NH}_{4}\right)_{6} \mathrm{Mo}_{7} \mathrm{O}_{24}\right.$ and $\mathrm{HgN}_{2} \mathrm{O}_{4} \mathrm{~T}$ ) were applied in addition to $0.5 \% \mathrm{w} / \mathrm{v}$ as inorganic nitrogen sources. After selecting yeast extract as the best organic nitrogen source, it was considered as a constant level in the basal medium.

\subsection{Optimization of physicochemical parameters}

Similarly, the effects of $\mathrm{pH}(6-10)$ and the inoculums size (OD 0.1-0.6) were already evaluated on strain growth and lipase production, as the physical parameters before being subjected to statistical optimization. Then, fermentation was performed in $250 \mathrm{~mL}$ shake flasks with $50 \mathrm{~mL}$ medium and incubated at $55^{\circ} \mathrm{C}$ in a shaker $(200 \mathrm{rpm})$ for about. All components were analyzed independently, and every test was performed in triplicate. The influential factors and levels for the enzyme activity were evaluated.

\subsection{Optimization of medium components by response surface methodology}

To analyze the experimental design data and to determine the optimum conditions for lipase production by Aeribacillus pallidus, response surface methodology (RSM) was applied. Box-Behnken Design (BBD) is one of the response surface methodology, with a three-level factorial design was used as the experimental design, to optimize the concentrations of three significant factors namely ratio $\mathrm{C} / \mathrm{N}$, $\mathrm{pH}$ and inoculums size for enhancing lipase production. The remaining factors were maintained at fixed concentration. The independent variables were studied at three different levels, low $(-1)$, medium $(0)$ and high ( +1$)$. All the experiments were carried out in triplicate and the average of lipase production obtained was taken as the response $(Y)$.

The relationship between dependent and independent variables is explained by the following secondorder polynomial equation and optimum levels were represented in response surface plots.

$\hat{Y}=b 0+b 1 X 1+b 2 X 2+b 3 X 3+b 11 X 12+b 22 X 22+b 33 X 32+b 12 X 1 X 2+b 13 X 1 X 3+b 23 X 2 X 3$

Where X1, X2 and X3 are the coded factors studied, b0 intercept, b1, b2, b3 linear coefficients, b11, b22, b33 squared coefficients, b12 , b13, b23 interaction coefficients. The model coefficients were estimated using multi linear regression. The significance of the coefficients is evaluated by multiple regression analysis based upon the F-test with unequal variance $(P<0.05)$. To check the compatibility of the proposed model with the obtained experimental data, we performed an analysis of variance. 


\subsection{Effects of commercial detergents on lipase activity}

The suitability of the lipase of Aeribacillus pallidus as a detergent additive, was determined by testing its stabilities and compatibilities towards a wide range of commercialized solid and liquid detergents. The list of liquid detergents included Dipex, (SOTUP, Sfax, Tunisia), Ariel (Procter \& Gamble, Switzerland), Skip (Unilever, France). and Judy (Ennadhafa, Sfax, Tunisia).. The solid detergents used were Nadhif(HenkelAlki, Tunisia), Dixan (Henkel-Alki, Tunisia),, Ariel(Procter \& Gamble, Switzerland), and Omo (Unilever, France).

In order to check lipase of Aeribacillus pallidus stability and compatibility with detergents, the mentioned commercial detergents were diluted in tap water to obtain a final concentration of $7 \mathrm{mg} / \mathrm{mL}$ (to simulate washing conditions). The endogenous lipolytic enzymes present in these laundry detergents were inactivated by heating the diluted detergents for $1 \mathrm{~h}$ at $90^{\circ} \mathrm{C}$, prior to the addition of the purified enzymes. $15 \mathrm{U} / \mathrm{mL}$ of lipase of Aeribacillus pallidus was shake-incubated with each laundry detergent for $30 \mathrm{~min}$ at different temperature $30,40,50$ and $60^{\circ} \mathrm{C}$, and residual activity was determined at $\mathrm{pH} 10$ and $65^{\circ} \mathrm{C}$ using TC4 as a substrate.

The enzyme activity of a control (without any detergent), incubated under similar conditions, was taken as $100 \%$.

\subsection{Removal of oil spot from cotton fabrics}

New white cotton cloth pieces $(5 \times 5 \mathrm{~cm})$ were speckled with lubricating oil and used to stimulate the washing conditions and determine the efficiency of lipase of Aeribacillus pallidus as a biodetergent additive compared. The endogenous lipases found in Dixan liquid laundry detergent were inactivated by heating the diluted detergents for $1 \mathrm{~h}$ at $90^{\circ} \mathrm{C}$ prior to the addition of the purified tested enzyme. The stained cloth pieces were shake-incubated $(220 \mathrm{rpm})$ in different wash treatments at $50{ }^{\circ} \mathrm{C}$ for $30 \mathrm{~min}$ in Erlenmeyer $250 \mathrm{~mL}$ containing a total volume of $100 \mathrm{~mL}$ of: tap water, Dixan detergent $(7 \mathrm{mg} / \mathrm{mL}$ in tap water), and detergent added with GPL $(15 \mathrm{U} / \mathrm{mL})$. After treatment, the cloth pieces were taken out, rinsed with water, dried and submitted to visual observation to examine the stain removal effects of the enzymes. The untreated blood-stained piece of cloth was taken as a control.

\section{Abbreviations}

one-factor-at-a-time (OFAT)

Aeribacillus pallidus lipase (GPL)

Thyna Petroleum Services (TPS)

Carbone/azote ratio ( $\mathrm{C} / \mathrm{N}$ ratio)

Response Surface Methodology (RSM) 


\section{Declarations}

Conflict of interest The authors declare that they have no confict of interest.

Ethical approval This article does not contain any studies with human participants or animals performed by any of the authors.

Availability of data and material : The datasets used and/or analysed during the current study are available from the corresponding author on reasonable request.

\section{Acknowledgements}

This work is a part of a doctoral thesis by Ameni Ktata whose research was supported financially by Ministère de l'enseignement supérieur et de la recherche scientifique-Tunisia through a grant to Laboratoire de Biochimie et de Génie Enzymatique des Lipases-ENIS.

\section{References}

Abdel-Fattah YR (2002) Optimization of thermostable lipase production from a thermophilic Geobacillus sp. using Box-Behnken experimental design. Biotechnol Lett. 24: 1217-1222. Al-mhanna MNM (2010) Observation of Crabtree effect and diauxic behaviour of yeast by using absorption. Chem. Eng. Trans. 21: 1465-1470. Basri M, Rahman RNZRA, Ebrahimpour A, Salleh AB, Gunawan ER, Rahman MBA (2007) Comparison of estimation capabilities of response surface methodology (RSM) with artificial neural network (ANN) in lipase- catalyzed synthesis of palm-based wax ester, BMC Biotechnol. 7: 53. Ben Bacha A, Moubayed NMS , Abid I (2015) Themostable, alkaline and detergent-tolerant lipase from newly isolated thermophilic Bacillus stearothermophilus. Indian J Biochem Biophys.Vol, 52, April,pp 179-188. Bradford M.M (1976) A rapid and sensitive method for the quantitation of microgram quantities of protein utilizing the principle of protein-dye binding, Anal Biochem. $72: 248-254$. Boran R, Ugur A, Sarac N, Ceylan, 0 (2019) Characterisation of Streptomyces violascens 0C125-8 lipase for oily wastewater treatment. 3 Biotech 9:5 Bora L, Kalita MC (2007) Production and Optimization of Thermostable lipase from a Thermophilic Bacillus sp LBN 4, The Internet J Microbiol. (4)1. ISSN1937-8289. Bora L, Bora M (2012) Optimization of extracellular thermophilic highly alkaline lipase from thermophilic Bacillus sp. isolated from hot spring of Arunachal Pradesh, India. Braz J Microbol. 43: 30-42. Box G, Behnken D (1960) Some new three-level designs for the study of quantitative variables, Technometrics. 2455-475. Chamkha M, Mnif S, Sayadi S (2008) Isolation ofa thermophilic and halophilic tyrosol-degrading Geobacillus fromaTunisian high-temperature oil field, FEMS Microbiol Lett. 283 :23-29. Das A, Shivakumar S, Bhattacharya S, Shakya S, Swathi S (2016) Purification and characterization of a surfactant-compatible lipase from Aspergillus tamarii JGIF06 exhibiting energyefficient removal of oil stains from polycotton fabric, 3 Biotech. 6 131, http://dx.doi.org/10.1007/s13205-016- 0449-z. Dong H, Gao S, Han S, Cao S (1999) Purification and characterization of a Pseudomonas sp. lipase and its properties in non-aqueous media, Appl. Microbiol. Biotechnol. 30 :251-256. Dharmsthiti S, Kuhasuntisuk B (1998). Lipase from Pseudomonas aeruginosa LP602: biochemical properties and application for wastewater treatment, J. 
Ind. Microbiol. Biotechnol. 21: 75-80. Esakkiraj P, Prabakaran G, Maruthiah T, Immanuel G, Palavesam, A (2014) Purification and characterization of halophilic alkaline lipase from Halobacillus sp. DOI, Proc Natl Acad Sci India, Sect B. doi:10.1007/s40011-014-0437-1 Eltaweel MA, Rahman RNZRA, Salleh AB, Basri M (2005) An organic solvent- stable lipase from Bacillus sp. strain 42. Ann Microbiol. 55: 187-192. FerreiraDias S, Sandoval G, Francisco P, Valero F (2015). The potential use of lipases in the production of fatty acid derivatives for the food and nutraceutical industries, Electron. J. Biotechnol. 16 Gaur R, Gupta A, Khare SK (2008) Lipase from solvent tolerant Pseudomonas aeruginosa strain: Production optimization by response surface methodology and application, Bioresour Technol. 99 :4796-4802. Gargouri M., Akacha NB, Kotti $F$,Ben Rajeb I (2008) Voie de la lipoxygénase valorisation d huiles végétales et biosynthèse de flaveurs. Biotechnol. Agron. Soc. Environ. 12:185-202. Gerritse G., Hommes RW, Quax WJ (1998) Development of a lipase fermentation process that uses a recombinant Pseudomonas alcaligenes strain. J Appl Environ Microbiol;64:2644-51. Ghanem, EH, Al-Sayeed, HA, Saleh, KM (2000) An alkalophilic thermostable lipase produced by a new isolate of Bacillus alcalophilus, World $\mathrm{J}$ Microb Biot. 16 : 459-464. Ghribi D, Mnif I, Boukedi H, Radhouan K, Chaabouni ES (2011) Statistical optimization of medium components for economical production of Bacillus subtilis surfactin, a biocontrol agent for the olive moth Prays oleae. Afr J Microbiol Res $5: 4927$ - 4936. Ghribi D, Sayari A, Gargouri,Y, Bezzine S (2009) Improvement of Staphylococcus xylosus lipase production through optimization of the culture conditions, Eur. J. Lipid Sci. Technol. 111: 967-971. Gowland P, Kernick M, Sundaram TK (1987) Thermophilic bacterial isolates producing lipase, FEMS Microbiol Lett. 48: 339-43. GuptaN, Sahai V, Gupta R (2007) Alkaline lipase from a novel strain Burkholderia multivorans : Statistical medium optimization and production in a bioreactor. Process Biochem, 42:518-526. Haaland PD (1989) Experimental design in biotechnology. Vol. 105.: CRC press. Hasan F, Shah AA, Hameed A (2006) Industrial applications of microbial lipases, Enzyme Microb. Technol, 235-251. Houde A, Kademi A, Leblanc D (2004) Lipases and their industrial applications. Applied Biochemistry and Biotechnology. pp 155-170 Hoshino E, Chiwaki M, Suzuki A, Murata M (2000) Improvement of cotton cloth soil removal by inclusion of alkaline cellulase from Bacillus sp. KSM-635 in detergents. J Surfactants Deterg.3:317-326. He YQ, Tan TW (2006) Use of response surface methodology to optimize culture medium for production of lipase with Candida sp, J Mol Catal B: Enzym. 43: 99-125. Jaouadi B, Ellouz-Chaabouni S, Ali M, Messaoud E, Naili B, Dhouib A, Bejar S (2009) Excellent laundry detergent compatibility and high dehairing ability of the Bacillus pumilus CBS alkaline proteinase (SAPB). Biotechnol. Bioproc. Eng. 14: 503- 512 Jia J, Yang Xf, Wu ZQ, Zhang ZL, Guo H, Lin CSK, Wang J, Wang Y (2015) Optimization of Fermentation Medium for Extracellular Lipase Production from Aspergillus niger Using Response Surface Methodology, BioMed Res Int. http://dx.doi.org/10.1155/2015/497462. Kaushik R, Saran S, Isar J, Saxena RK (2006) Statistical optimization of medium components and growth conditions by response surface methodology to enhance lipase production by Aspergillus carneus. J Mol Catal B Enzym. 40(3):121-6. Ladidi MA, Nooh HM , Oslan SN ,Salleh AB (2017) Optimization of physical conditions for the production of thermostable T1 lipase in Pichia guilliermondii strain SO using response surface methodology, BMC Biotechnology. 17:78. Lee DW, Koh YS, Kim KJ, Kim BC, Choi HJ, Kim DS, Suhartono MT, Pyun YR (1999) Isolation and characterization of a thermophilic lipase from Bacillus thermoleovorans ID-1. FEMS Microbiol Lett. 179: 393-400 Li X, Qian P, Wu SG, Yu HY (2014) 
Characterization of an organic solvent-tolerant lipase from Idiomarina sp. W33 and its application for biodiesel production using Jatropha oil. Extremophiles 18:171-178. Lotti M., Monticelli S, Montesinos J.L, Brocca S, Valero F, Lafuente J (1998) Physiological control on the expression and secretion of Candida rugosa lipase. Chem Phys Lipids 93:143-148. Madigan MT, Martinko JM, Parker J, Sanchez Perez M (2003) Biologia de los microorganismos: Brock. 10th ed. Pearson, Prentice Hall, pp. 156-160. Muralidhar RV, Chirumamila RR, Marchant R, Nigam P, (2001) Biochem. Eng. J. 9 17-23 Marques TA, Baldo C, Borsato D, Buzato JB, Celligoi MAPC (2014) Production and partial characterization of a thermostable, alkaline and organic solvent tolerant lipase from Trichoderma atroviride 676. Int J Sci Technol Res 3:77-83. Mates A, Sudakevitz D (1973) Production of lipase by Staphylococcus aureus under various growth conditions, J Appl Bacteriol. 36 : 219-226. Miñana-Galbis D, Pinzón DL, Lorén JG, Manresa A, Oliart-Ros, RM (2010) Reclassification of Geobacillus pallidus (Scholz et al. 1988) Banat et al. 2004 as Aeribacillus pallidus gen. nov., comb. Nov, Int J Syst Evol Microbiol. 60: 1600-1604. Mnif S, Sayadi S, Chamkha M (2014) Biodegradative potential and characterization of a novel aromaticdegrading bacterium isolated from a geothermal oil field under saline and thermophilic conditions, Int. Biodeter. Biodegr. 86 :258-264. Muralidhar RV, Chirumamila RR,Marchant R, Nigam P (2001) A response surface approach for the comparison of lipase production by Candida cylindracea using two different carbon sources. Biochemical Engineering Journal 17-23. Nagarajan S (2012) Appl. Biochem. Biotech. 168,1163-1196. Nouroozi AS, Rezaei S, Khoshnevis N, Doosti M, Hajihoseini R, Khoshayand MR, Faramarzi MA (2015) Medium based optimization of an organic solvent tolerant extracellular lipase from the isolated halophilic Alkalibacillus salilacus .Extremophiles. 19: 933-947. Pandey A, Selvakumar P, Carlos RS, Nigam P (1999) Solid state fermentation for the production of industrial enzymes. Current Science 77: 149-162 Strobel R, Sullivan G (1999) Experimental design for improvement of fermentations. In: Demain AL, Davies JE, eds. Manual of Industrial Microbiology and Biotechnology. Washington: ASM Press, pp. 80-93. Sharma R, Chisti Y, Banerjee UC (2001) Production, purification, characterization, application of lipases. Biotechnol Adv. 19: 627-662. Sharma R, Soni SK, Vohra RM, Jolly RS, Gupta LK, Gupta JK (2002) Production of extracellular alkaline lipase from a Bacillus sp. RSJ1 and its application in ester hydrolysis, Ind J Microbiol. 42 :49-54. Sharon C, Nakazato M, Ogawa HI, Kato Y (1998) Lipase induced hydrolysis of castor oil: effect of various metals, Journal of Industrial Microbiology and Biotechnology, 292-295. Soo EL, Salleh AB, Basri M, Rahman RNZA, Kamaruddin K (2004) Response surface methodological study on lipase-catalyzed synthesis of amino acid surfactants. Process Biochem. 39: 1511-1518. Sooch BS, Kauldhar BS (2013) Influence of multiple bioprocess parameters on production of lipase from Pseudomonas sp. BWS-5. Braz. Arch. Biol. Technol. 56(5): 711-721. Sugihara A, Tani T, Tominaga Y (1991) Purification and characterization of a novel thermostable lipase from Bacillus sp. J Biochem. 109: 211-215. Teng Y, Xu Y (2008) Culture condition improvement for whole-cell lipase production in submerged fermentation by Rhizopus chinensis using statistical method. Bioresour Technol. 99: 3900-3907. Veerapagu M, Narayanan AS, Ponmurugan K, Jeya KR (2013) Screening, selection, identification, production and optimization of bacterial lipase from oil spilled soil, Asian $\mathrm{J}$. Pharm. Clin. Res. 6 62-67. Wang Y, Srivastava KC, Shen GJ, Wang HY (1995) Thermostable alkaline lipase form a newly isolated thermophilic Bacillus strain A30-1 (ATCC 53841), J. Ferment. Bioeng. 79 :433-438. Wu QL, Chen T, Gan Y, Chen X, Zhao XM (2007) Optimization of riboflavin production by 
recombinant Bacillus subtilis RH44 using statistical designs, Appl Microbiol Biotechnol. 76: 783-794. Yoo HY, Simkhada JR, Cho SS, Park DH, Kim SW, Seong CN, Yoo JC (2011) A novel alkaline lipase from Ralstonia with potential application in biodiesel production. Bioresour Technol 102:6104-6111. Zin NBM, Yusof BM, Oslan SN, Wasoh H, Tan JS (2017) Utilization of acid pretreated coconut dregs as a substrate for production of detergent compatible lipase by Bacillus stratosphericus. AMB Expr 7:131.

\section{Tables}

Table 1: Experimental design using Box-Behnken of three independent variables with their actual values showing the experimental and predicted responses.

The experiments were conducted three times.

\begin{tabular}{|l|l|l|l|l|l|}
\hline Run order & X1 & X2 & X3 \\
& & pH & $\begin{array}{l}\text { Inoculum Size } \\
\text { (DO600) }\end{array}$ & \multicolumn{2}{|c|}{ Lipase Activity U/ml } \\
\cline { 5 - 6 } & & & & Experimental & Predicted \\
\hline 1 & 1 & 6 & 0.3 & $50 \pm 0.9$ & 51 \\
\hline 2 & 4 & 6 & 0.3 & $40 \pm 0.12$ & 41 \\
\hline 3 & 1 & 10 & 0.3 & $68 \pm 0.92$ & 67 \\
\hline 4 & 4 & 10 & 0.3 & $52 \pm 0.13$ & 51 \\
\hline 5 & 1 & 8 & 0.1 & $48 \pm 0.24$ & 47.5 \\
\hline 6 & 4 & 8 & 0.1 & $30 \pm 0.22$ & 29.5 \\
\hline 7 & 1 & 8 & 0.5 & $42 \pm 0.84$ & 42.5 \\
\hline 8 & 4 & 8 & 0.5 & $34 \pm 0.71$ & 34.5 \\
\hline 9 & 2.5 & 6 & 0.1 & $30 \pm 0.31$ & 29.5 \\
\hline 10 & 2.5 & 10 & 0.1 & $48 \pm 0.42$ & 49.5 \\
\hline 11 & 2.5 & 6 & 0.5 & $38 \pm 0.1$ & 36.5 \\
\hline 12 & 2.5 & 10 & 0.5 & $42 \pm 0.2$ & 42.5 \\
\hline 13 & 2.5 & 8 & 0.3 & $48 \pm 0.12$ & 48 \\
\hline 14 & 2.5 & 8 & 0.3 & $48 \pm 0.12$ & 48 \\
\hline 15 & 2.5 & 8 & 0.3 & $48 \pm 0.12$ & 48 \\
\hline 16 & 2.5 & 8 & 0.3 & $48 \pm 0.12$ & 48 \\
\hline & & & & & \\
\hline
\end{tabular}

Table 2: ANOVA analysis for lipase activity in Box-Behnken experiments obtained by Aeribacillus pallidus. 


\begin{tabular}{cccccc}
\hline $\begin{array}{c}\text { Source of } \\
\text { variation }\end{array}$ & $\begin{array}{c}\text { Sum of } \\
\text { squares }\end{array}$ & $\begin{array}{c}\text { Degree of } \\
\text { freedom }\end{array}$ & Mean square & $\begin{array}{c}\text { F- } \\
\text { value }\end{array}$ & Significance \\
\hline Regression & $1.3078 \mathrm{E}$ & 9 & $1.4531 \mathrm{E}+0003$ & 87.183 & $* * *$ \\
& +0003 & & & & \\
Residual & $1.000 \mathrm{E}$ & 6 & $1.6667 \mathrm{E}+0000$ & \\
& +0001 & & & & \\
& & & & & \\
& $1.6667 \mathrm{E}$ & 15 & & & \\
\hline Total & & & & & \\
& & & & & \\
& & & & & \\
\end{tabular}

Table 3: Estimated effect, regression coefficient and corresponding $\mathrm{t}$ and $\mathrm{P}$ values for lipase activity in Box-Benkhen design experiments

\begin{tabular}{|c|c|c|c|c|c|c|}
\hline Noun & $\begin{array}{l}\text { Estimate } \\
\text { Coefficient }\end{array}$ & $\begin{array}{l}\text { Inflation } \\
\text { Factor }\end{array}$ & $\begin{array}{l}\text { Standard } \\
\text { deviation }\end{array}$ & t.exp & $\begin{array}{l}\text { Confidence } \\
\text { level (\%) }\end{array}$ & Signification \\
\hline $\mathrm{b}_{0}$ & 48 & 1.00 & 0.645 & 74.36 & $<0.01$ & $* * *$ \\
\hline $\mathrm{b}_{1}$ & -6.500 & 1.00 & 0.456 & $\begin{array}{l}- \\
14.24\end{array}$ & $<0.01$ & $* * *$ \\
\hline $\mathrm{b}_{2}$ & 6.500 & 1.00 & 0.456 & 14.24 & $<0.01$ & $* * *$ \\
\hline $\mathrm{b}_{3}$ & 0.000 & 1.00 & 0.456 & 0.000 & 100 & \\
\hline $\mathrm{b}_{1-1}$ & 1.750 & 1.00 & 0.645 & 2.71 & 3.512 & $*$ \\
\hline $\mathrm{b}_{2-2}$ & 2.750 & 1.00 & 0.645 & 4.26 & 0.532 & $* *$ \\
\hline$b_{3-3}$ & -11.250 & 1.00 & 0.645 & -17.43 & $<0.01$ & *** \\
\hline $\mathrm{b}_{1-2}$ & -1.500 & 1.00 & 0.645 & -2.32 & 5.9 & \\
\hline $\mathrm{b}_{1-3}$ & 2.500 & 1.00 & 0.645 & 3.87 & 0.824 & $* * *$ \\
\hline $\mathrm{b}_{2-3}$ & -3.500 & 1.00 & 0.645 & -5.42 & 0.163 & ** \\
\hline
\end{tabular}

t.exp is the value of variables determined by student's test.

***: Significant for $0.0001<$ p-value $<0.001$

**: Significant for $0.001<\mathrm{p}$-value $<0.01$ 
$*$ : Non significant for $\mathrm{p}$-value $>0.05$

\section{Figures}

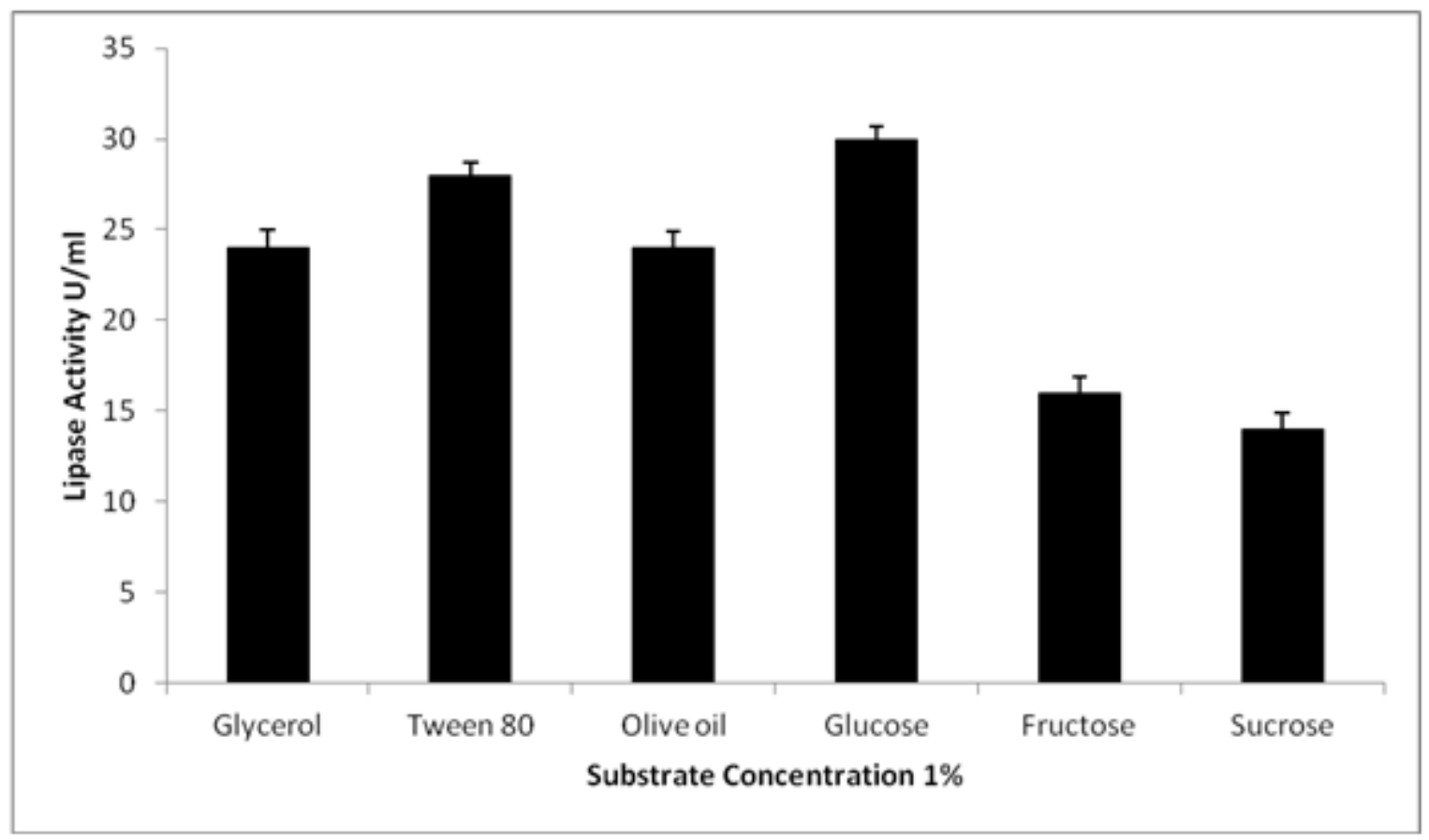

\section{Figure 1}

The effect of different carbon sources on lipase activity obtained at $65^{\circ} \mathrm{C}, \mathrm{pH} 10$, for $22 \mathrm{~h}$ by Aeribacillus pallidus. The values are average of three independent experiments and the error bars represent standanrd deviation.

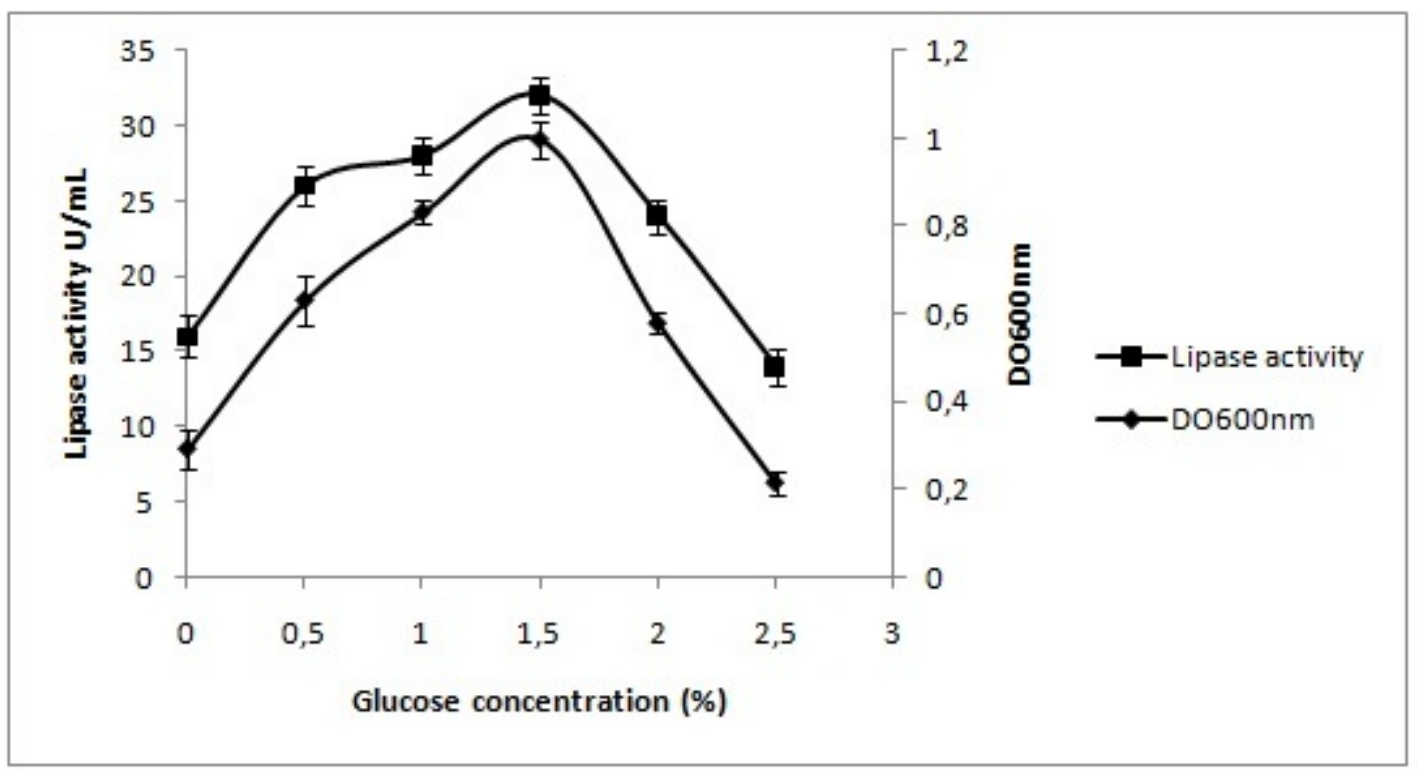

Figure 2 
Aerobic growth of Aeribacillus pallidus on the optimized culture medium with different glucose concentration (filled triangle). The effect of different concentrations of glucose on lipase production at 65 ${ }^{\circ} \mathrm{C}, \mathrm{pH} 10$, for $22 \mathrm{~h}$ ( filled square). The values are average of three independent experiments and the error bars represent standard deviation.
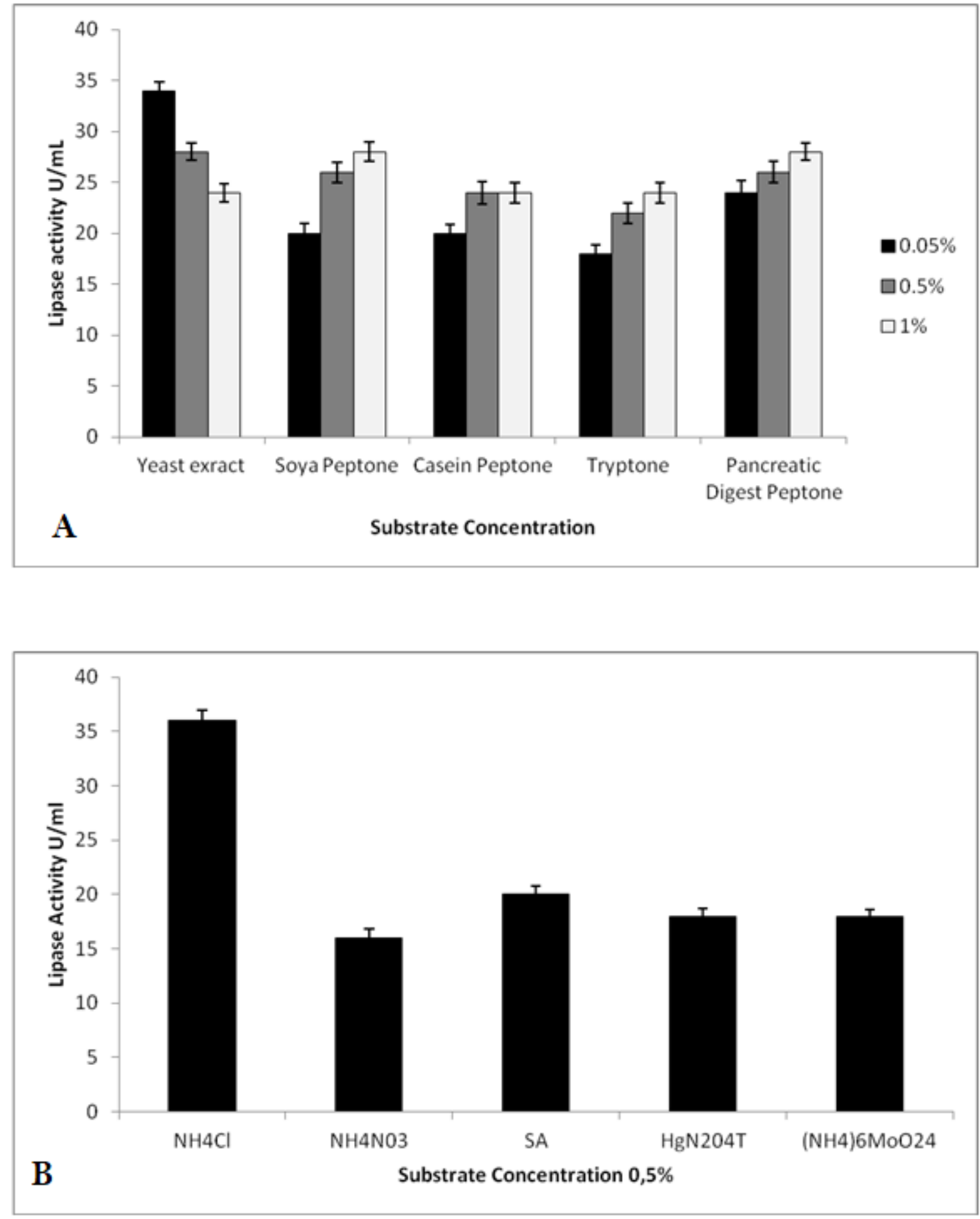

Figure 3

(a) Effects of different organic nitrogen sources on lipase production at $65^{\circ} \mathrm{C}, \mathrm{pH} 10$, for $22 \mathrm{~h}$ of incubation by Aeribacillus pallidus using glucose as a carbon source kept at $15 \mathrm{~g} / \mathrm{l}$.. (b) Effects of 
different inorganic nitrogen sources on lipase production at $65^{\circ} \mathrm{C}, \mathrm{pH} 10$, for $22 \mathrm{~h}$ of incubation by Aeribacillus pallidus

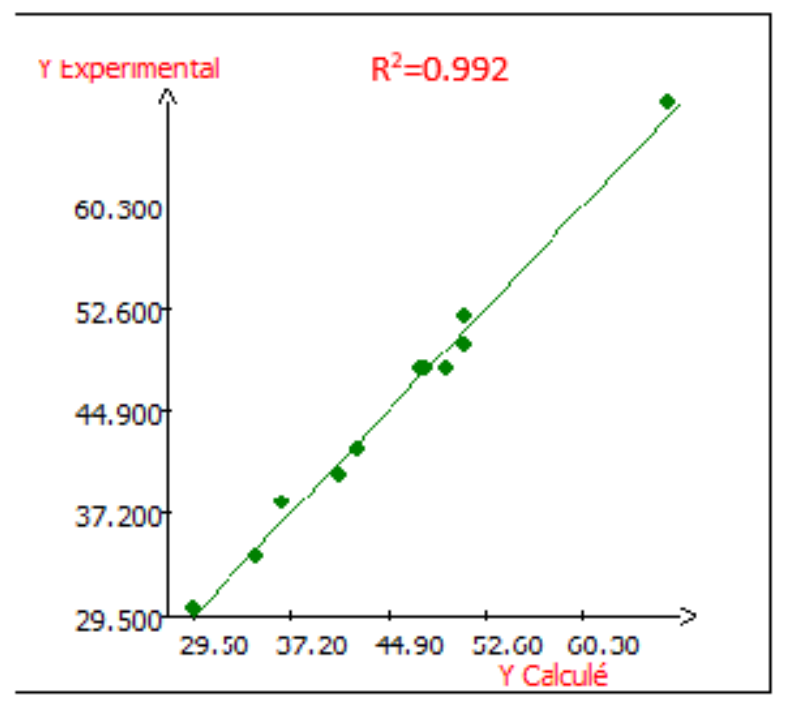

\section{Figure 4}

Validation of Predicted versus Actual values. The straight line of regression with data points across indicates the suitability of the model, agreement between predicted and actual values and it conforms to the assumption of data point representation 

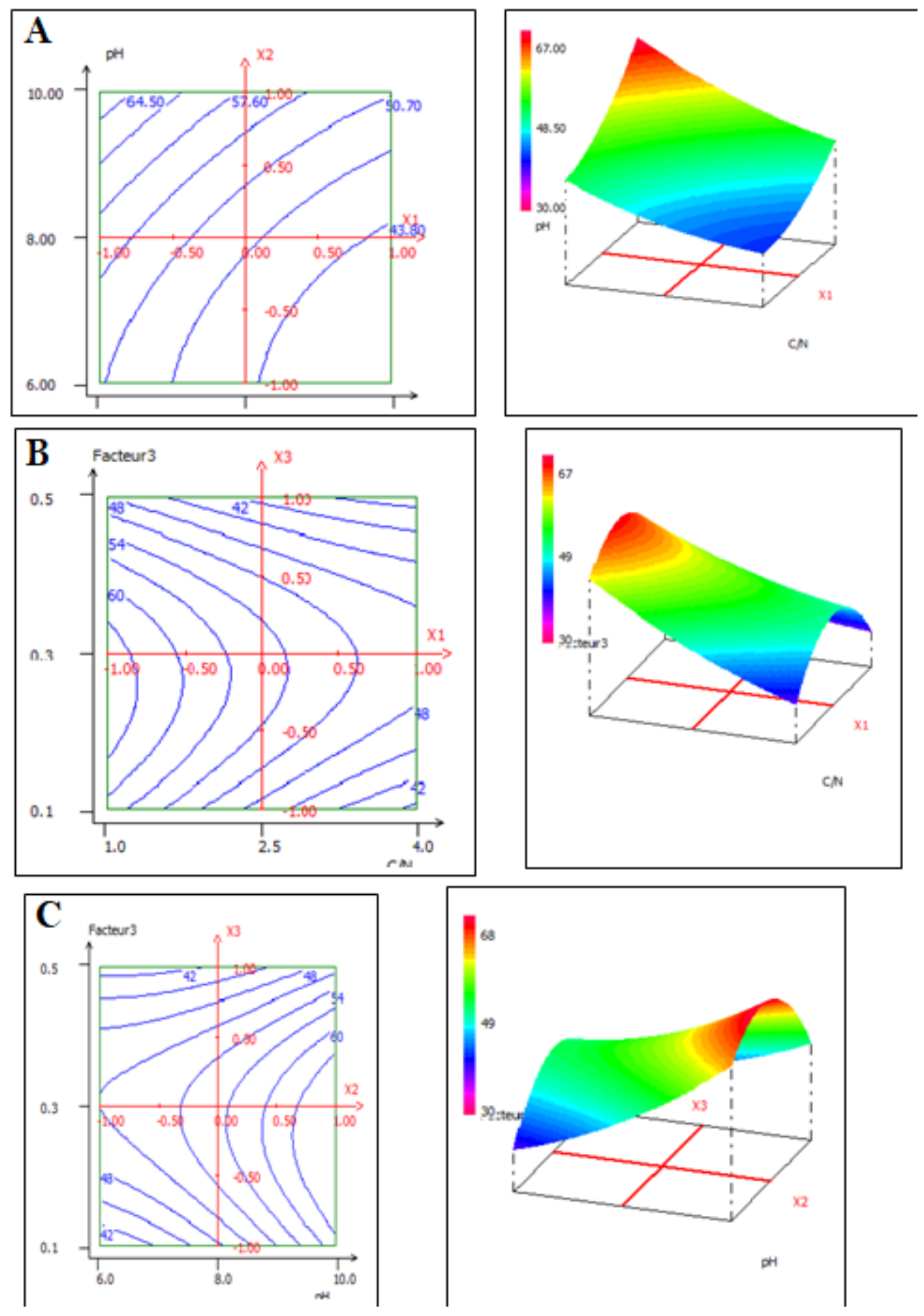

Figure 5

(a) Effect of ration $\mathrm{C} / \mathrm{N}$ and $\mathrm{pH}$ on lipase activity: response surface plot (right) and its contour plot (left) of interaction between the two factors. (b) Effect of ration $\mathrm{C} / \mathrm{N}$ and inoculums size on lipase activity: response surface plot (right) and its contour plot (left) of interaction between the two factors. (c) Effect of ration $\mathrm{pH}$ and inoculums size on lipase activity: response surface plot (right) and its contour plot (left) of interaction between the two factors. 


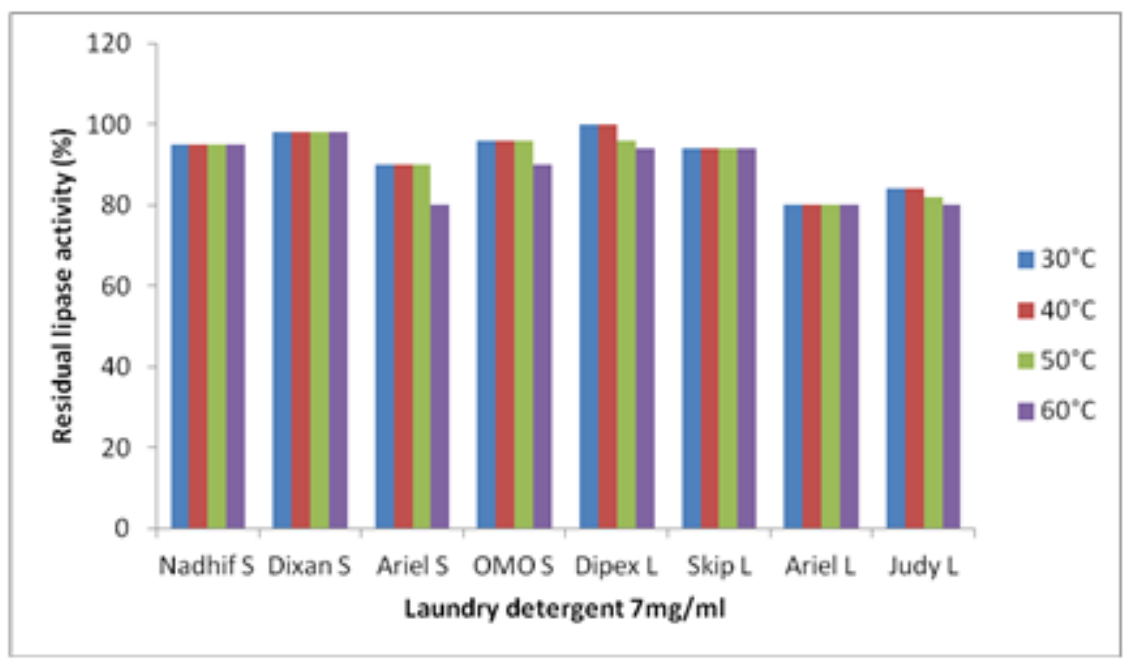

\section{Figure 6}

Stability of the purified lipase (GPL) in the presence of liquid and solid laundry detergents. Enzyme activity of the control sample, which contained no additive and incubated under similar conditions, was taken as $100 \%$. Each point represents the mean of three independent experiments.

a

b

c

d

I.

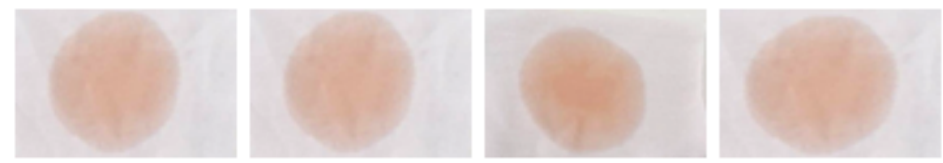

II.
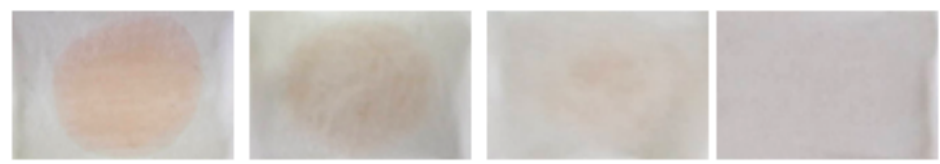

\section{Figure 7}

Washing performance analysis test of GPL in the presence of the commercial detergent Dixan (a) Oilstained cloth washed with tap water; (b) Oil-stained cloth washedwith Dixan detergent $(7 \mathrm{mg} / \mathrm{ml})$, (c) Oilstained cloth washed with GPL only (d) Oil-stained cloth washed with Dixan added with GPL (15 U/ml). I: untreated cloths (control) and II: treated cloths. 